\title{
Plant conservation for the next decade: a celebration of Kew's 250th anniversary
}

\section{Stephen D. Hopper ${ }^{1}$}

The papers in this issue of Kew Bulletin were delivered at a conference with the above title in the Jodrell Laboratory of the Royal Botanic Gardens, Kew on 12 - 16 October, 2009. Attracting 193 registrants from 34 countries, 50 speakers (including 10 keynote speakers) and 55 poster presenters, the conference proved most successful, as the papers herein highlight.

Why was plant conservation chosen as the theme for such an important moment in the history of Kew? This certainly represents a significant shift in focus for the world's largest botanical garden. A brief historical analysis may help place this shift in context.

Although we have no first-hand history of Kew written for its 50th anniversary in 1809 or its centenary in 1859, the enterprise of empire was uppermost in the botanical science and economic botany of Kew during these eras under the respective leadership of Sir Joseph Banks and Sir William Hooker. By the sesquicentenary in 1909, staff had written a first history in which we were told (Bean \& Thiselton-Dyer 1908): "Kew is the headquarters of botanical science in the British Empire — one might, without extravagance, say in the whole world. That is its highest purpose. What Greenwich is to astronomy, the National Gallery to painting, the British Museum to archaeology, such is Kew to botany."

The Director, Professor Sir William Thiselton-Dyer (1908) emphasised the important work of Kew on economic botany as well as taxonomy at the time: "Kew, in truth, has no politics or any aim but to accomplish useful work."

Fifty years later, in celebrating the bicentenary of Kew, the essential thrust of the organisation was identified both as a centre for botanical science and as a visitor attraction (Turrill 1959a): "The Royal Botanic Gardens, Kew, function essentially as a botanical not as a horticultural institution. Nevertheless, the Gardens proper as open to the general public are very beautiful and give recreation and pleasure to thousands of visitors who are not botanists."

This view of Kew as a centre of scientific excellence in botany was further reinforced by Vistas in Botany
(Turrill 1959b), an edited volume of essays across the discipline written by global experts of the day. With considerable prescience, the then Director, Sir George Taylor wrote in Turrill (1959b): "The massive contributions to taxonomy [by Kew] have tended to overshadow the more limited output from the Jodrell Laboratory ... [for which] it is confidently expected that there will be early significant expansion in ... [its] activities]. ...Kew is proud of its long traditions of service to botanical science and horticulture and is confident in its power not only to maintain its high position but is poised to add further lustre to its reputation in the field of botanical research in its widest sense" (Taylor 1959).

Over the subsequent 50 years, Kew's Jodrell Laboratory has indeed risen to international eminence alongside the Herbarium, Library, Art and Archives, and RBG, Kew was inscribed on the World Heritage List in 2003, according contemporary global recognition of its collections, gardens and scientific programmes - see the recent histories of Kew by Desmond (2006) and Paterson (2008).

While the focus on the science of plant and fungal diversity and the sustainable use of plants continue to underpin the work of Kew, dramatic changes in the global environment precipitated a new focus on conservation over the past four decades. Professor Sir Ghillean Prance, Director of Kew from 1988 to 1999, provides in this issue an authoritative review of how this happened. The change of focus towards plant conservation was initiated under the visionary directorship of Professor Jack Heslop-Harrison (McDowell 1996; Desmond 2006; Gunning \& Heslop-Harrison 2005), and carried through by his successors and their staff and global partners to today's cutting edge projects, including the Millennium Seed Bank Partnership.

In recent years, Kew has formulated a new set of corporate strategies placed under the umbrella of the Breathing Planet Programme. This is a global partnership programme of existing activities which will be scaled up, resources willing, over the next decade with the aim of inspiring and delivering science-based plant and fungal conservation worldwide, enhancing the quality of life (Fig. 1).

\footnotetext{
Accepted for publication December 2010.

1 Royal Botanic Gardens, Kew, Richmond, Surrey, TW9 3AB, UK.
} 


\section{Accelerating discovery and global access 2 2. Mapping plant diversity to plant and fungal diversity information and conservation priorities}

\section{Better conservation on the ground}

\section{Sustainable use of locally-} appropriate plant species

\section{... to help retain the Earth's major remaining wild biodiversity}

... to help plant-based adaptation to global change
5. Seed banking through the Millennium Seed Bank Partnership
6. Establishing a global network of partners in restoration ecology

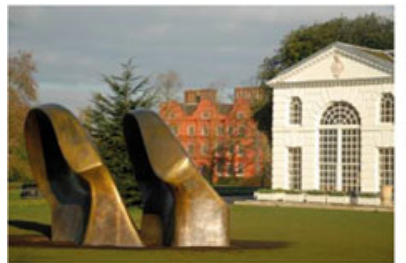

... to help recover lost plant productivity, diversity and carbon sequestration

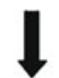

\section{Botanic Gardens as inspirational shop-fronts for plant diversity, sustainable living and innovative digital hubs}

Fig. 1. How botanic gardens might make a step change in scientific plant-based solutions to global environmental challenges: Kew's Breathing Planet Programme with global partners. Photos of RBG Kew, London, and Kings Park and Botanic Garden, Perth, S. D. Hopper.

Today, an assessment of global challenges and developments in plant conservation summarised in this volume is invaluable as humans face unprecedented global change. Global warming and the ongoing loss of biodiversity rank amongst the biggest issues humanity faces. Plant-based solutions undoubtedly will help contribute to seeing our way through to more sustainable lifestyles if we act in a timely and well-informed fashion. Kew and its global partners have a vital role to play in this regard. The papers herein elegantly exemplify the richness and depth of contemporary plant conservation.

The conference was opened by the UK's Parliamentary Under-Secretary of State for the Environment Huw Irranca-Davies, and divided thereafter across six themes: plant conservation: policies and politics; frontiers of plant conservation technology; plant conservation and agriculture; plant conservation: management and restoration; plant conservation and human cultures; and plant conservation: what can we afford to lose? The papers in this issue represent the breadth and depth of the content of the conference, and are arranged more or less in the same sequence as the six conference themes.

At the conference it was my pleasure to award the inaugural RBG, Kew International Medal to Dr Peter Raven, President of the Missouri Botanical Garden
(Fig. 2). This was for his distinguished, internationallyrecognised work aligned with the mission of Kew. Dr Raven provided an inspiring address on plant conservation at the conference dinner.

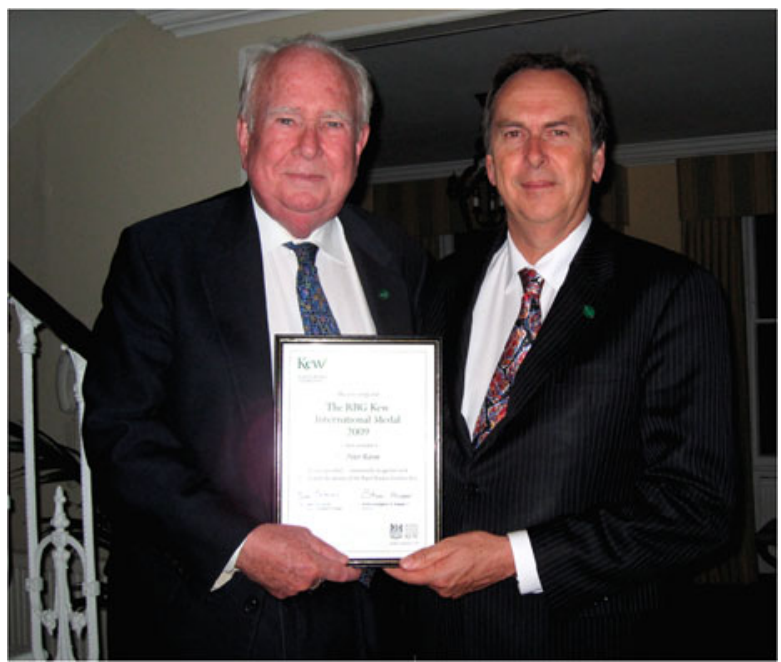

Fig. 2. Dr Peter Raven, President Missouri Botanical Garden, with the inaugural Kew International Medal citation, and Professor Stephen Hopper, Director (Chief Executive Officer and Chief Scientist), Royal Botanic Gardens, Kew. October 2009. 
I am grateful to the dedicated Kew staff who helped me on the Conference Organising Committee, to deliver such a successful international event: Dr Rogier de Kok, Dr Mike Fay, Dr Lauren Gardiner, Dr Eimear Nic Lughadha, Prof Hugh Pritchard, Ms Margaret Ramsay, Mr Hassan Rankou and Dr Rhian Smith.

\section{References}

Bean, W. J. \& Thiselton-Dyer, W. (1908). The Royal Botanic Gardens Kew: Historical and Descriptive. Cassell, London. Desmond, R. (2006). The History of the Royal Botanic Gardens Kew. Royal Botanic Gardens, Kew.

Gunning, B. E. S. \& Heslop-Harrison, Y. (2005). J. Heslop-Harrison Biography: Royal Botanic Gardens, Kew, 1970 - 1976 (accessed Dec 2010 at http:/ / homepage.ntlworld.com/genomes / jhhpdfs/19kew.pdf). In: B. E. S. Gunning (compiler) \& Y. Heslop-Harrison, Jack Heslop-Harrison, $1920-1998$ His life and career in science. Biography
1945 - 1998. (http://homepage.ntlworld.com/ genomes/jhh/jhh.htm)

McDowell, D. (1996). The Sixth Kew Environmental Lecture. Conservation at the cutting edge. The Environmentalist 16: $171-177$.

Paterson, A. (2008). The Gardens at Kew. Frances Lincoln, London.

Taylor, G. (1959). The Royal Botanic Gardens, Kew. In: W. B. Turrill (ed.), Vistas in Botany. A volume in honour of the bicentenary of the Royal Botanic Gardens, Kew, pp. 1 - 2. Pergamon Press, New York.

Thiselton-Dyer, W. (1908). Introduction. In: W. J. Bean \& W. Thiselton-Dyer, The Royal Botanic Gardens Kew: Historical and Descriptive, pp. xiii - xx. Cassell, London.

Turrill, W. B. (1959a). The Royal Botanic Gardens Kew. Past and Present. Herbert Jenkins, London.

(1959b) Vistas in Botany. A volume in honour of the bicentenary of the Royal Botanic Gardens, Kew. Pergamon Press, New York. 


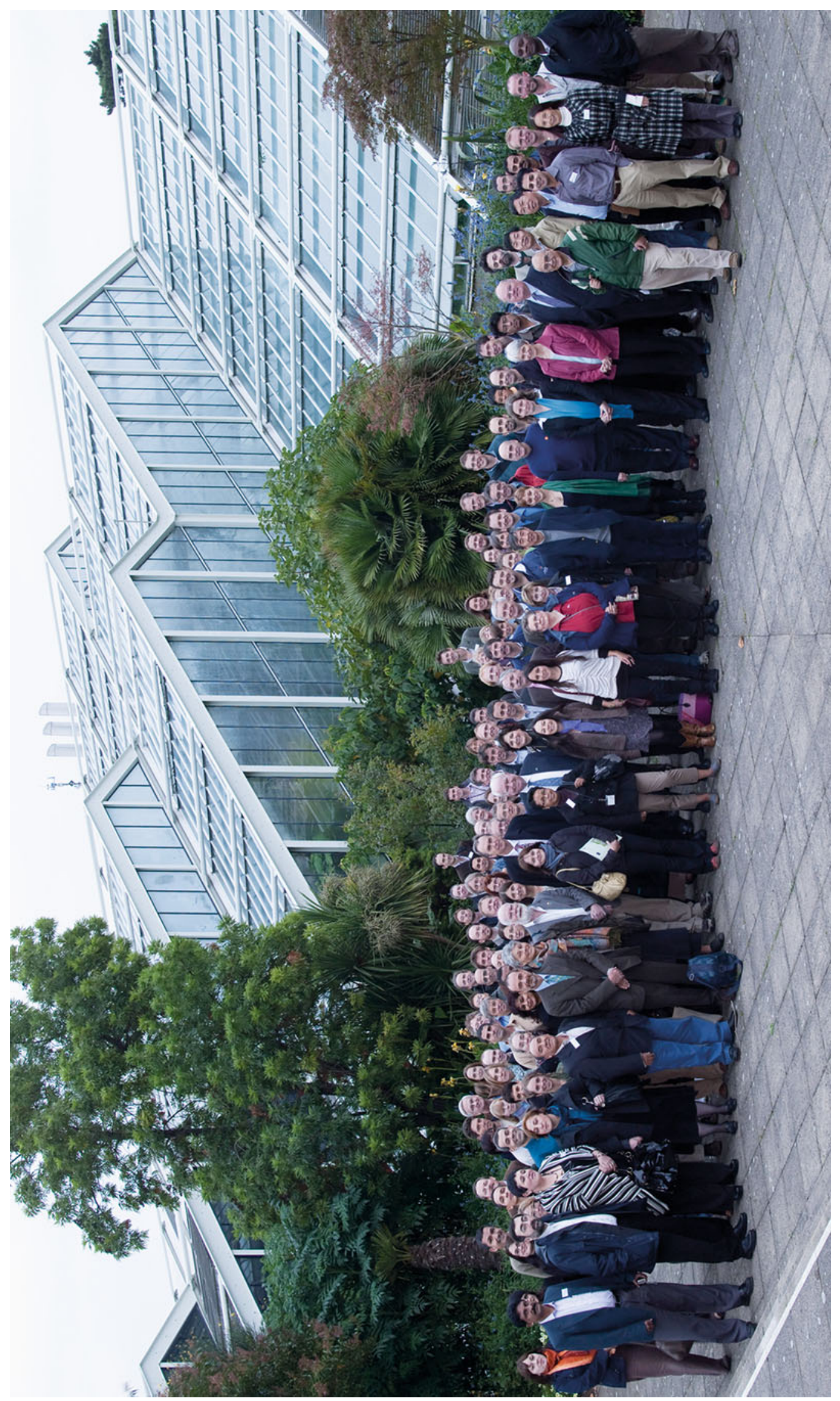

(c) The Board of Trustees of the Royal Botanic Gardens, Kew, 2011 